\title{
Variations of Particulate Matter Concentrations and Particle-Associated Substances in Latvia
}

\author{
Iveta Steinberga, Faculty of Geography and Earth Sciences, University of Latvia
}

\begin{abstract}
Concentrations of air pollutants mainly depend on meteorological conditions and pollutant emission levels. Airborne particulate matter $\left(\mathbf{P M}_{2.5}\right.$ and $\left.\mathbf{P} \mathbf{M}_{10}\right)$ concentrations were measured in Riga (Latvia) from the end of April to the end of December 2007. The collected particulate matter was analyzed for the anion, cation and heavy metal content. The seasonal variations of particulate matter concentrations were investigated, together with their relationships with meteorological parameters and other pollutant gases. The maximum daily concentration of $\mathrm{PM}_{2.5}$ and $\mathrm{PM}_{10}$ reached $52.5 \mu \mathrm{g} / \mathrm{m}^{3}$ in $\mathrm{June}$ and $83.4 \mu \mathrm{g} / \mathrm{m}^{3}$ in December, respectively.
\end{abstract}

Keywords - Particulate matter, $\mathrm{PM}_{2.5}, \mathrm{PM}_{10}$, Riga

\section{INTRODUCTION}

Just about 30 years ago British epidemiologists reported that there was no evidence for negative health effects from particulate matter pollution levels [1]. Nonetheless, in 2009 the Environmental Protection Agency of the U.S. reported that the daily pollution of particulate matter, which is experienced by most Americans, is associated with premature deaths [2].

Ambient air pollution has adverse effects on respiratory and cardiovascular systems influencing lung functions, increasing risk of pneumonia, etc. [3]

Particulate matter is a complex mixture of suspended solid and liquid particles. These particles come in many different size ranges, such as coarse, fine and ultra fine. Particles with diameters between 2.5 and $10 \mu \mathrm{m}$ can enter lungs, however, those with the diameter of less than or equal to $2.5 \mu \mathrm{m}$ can reach alveolus and from there enter the blood-stream. But there is still a fundamental lack of understanding underlying the mechanisms of their toxicity; one of the widely accepted hypotheses is that the toxicity of particulates depends not only on their size, but also on their composition, both of which depend on location, time of year and meteorological conditions [4].

The combustion of fossil fuels, such as coal, oil and petrol, can produce coarse particles, fly ash, fine particles and secondary particles.

Some studies show that water soluble ions, such as sulfate and nitrate, accounted for one-third or more of the aerosol particles in some urban regions [5, 6, 7]. Moreover, the relative abundances of the above mentioned ions play an important role in determining the hygroscopicity of atmospheric aerosols [8]; and so their tendency to absorb water at high relative humidity leads to a decrease in visibility $[9,10,11]$.

The interest of this research is to find relationships between particulate matter concentrations, their composition and meteorological conditions. Some studies performed on airborne particulates have revealed that heavy metals like $\mathrm{Pb}$, $\mathrm{Ni}, \mathrm{Cd}$, As adsorbed by particulate matter may play an important role in generation of adverse health effects.

\section{METHODOLOGY}

\section{A. Study area}

During the last 15 years in Latvia, a significant decrease in total emission of gaseous pollutants has been detected, e.g. the total $\mathrm{SO}_{2}$ emissions decreased by $96.1 \%, \mathrm{NO}_{\mathrm{x}}$ emissions by $42.9 \%$ and $\mathrm{NH}_{3}$ emissions by $72 \%$. The reduction is mainly due to the use of fuels with lover content of sulphur, as well as switching from solid and liquid types of fuel to natural gas and biomass, due to fuel consumption and the increasing use of catalyst cars. The main sources of the particulate matter emission are the commercial and residential sectors. Combustion of wood and wood products account for $71.7 \%$ of total $\mathrm{PM}_{10}$ emission, against industry $-10.2 \%$, traffic -8.9 $\%$ and agriculture $-5.8 \%$ [19].

The long-range pollution transport significantly contributes to the $\mathrm{PM}_{10}$ pollution level caused by the geographical position and close proximity of the sea. Secondary particles are mainly formed by oxidation of $\mathrm{SO}_{2}$ and $\mathrm{NO}_{\mathrm{x}}$ and reaction with ammonia. Long-range pollution transport contributes to about $80 \%$ for oxidized sulphur, $75 \%$ for oxidized and reduced nitrogen from the total deposition in Latvia [20].

In addition, there is a large contribution from natural sources, e.g. soil dust and sea spray.

The study area is situated in the city of Riga (Latvia). Riga is the capital of Latvia and the biggest city in the country (about 0.7 millions inhabitants, accounting for $32 \%$ of the Latvian population) [21].

The monitoring station type is classified as urban-industrial, and it is located close to the Freeport of Riga territory. Freeport of Riga is a significant global and regional cargo supplier. In 2010 the volume of the transhipped cargoes has reached 30.5 million tons, 4040 vessels were mounted. The main types of cargo handled are containers, various metals, timber, coal, mineral fertilizers, chemical cargoes, and oil and food products [22]. 
TABLE 1

MEASUREMENT METHODS, ACCURACY OF PARTICULATE MATTER RELATED SUBSTANCES

\begin{tabular}{|l|l|l|l|}
\hline Parameter & Methodology & Accuracy, \% & Period \\
\hline $\mathrm{SO}_{4}$ & LVS EN ISO10304-1:2004 & 3.2 & $03.08-1.09,03.12-31.12$ \\
\hline $\mathrm{NO}_{3}$ & LVS EN ISO10304-1:2004 & 2.7 & $03.08-1.09,03.12-31.12$ \\
\hline $\mathrm{Cl}$ & LVS EN ISO10304-1:2004 & 5 & $03.08-1.09,03.12-31.12$ \\
\hline $\mathrm{Ca}$ & LVS EN ISO 17294-2:2005 & 2 & $01.06-30.06,02.10-02.11$ \\
\hline $\mathrm{Mg}$ & LVS EN ISO 17294-2:2005 & 3 & $01.06-30.06,02.10-02.11$ \\
\hline $\mathrm{Na}$ & LVS EN ISO 17294-2:2005 & 4 & $01.06-30.06,02.10-02.11$ \\
\hline $\mathrm{K}$ & LVS EN ISO 17294-2:2005 & 3 & $01.06-30.06,02.10-02.11$ \\
\hline $\mathrm{As}$ & LVS EN ISO 17294-2:2005 & 6 & $28.04-24.05,04.07-30.07,05.09-01.10,07.11-30.11$ \\
\hline $\mathrm{Cd}$ & LVS EN ISO 17294-2:2005 & 5 & $28.04-24.05,04.07-30.07,05.09-01.10,07.11-30.11$ \\
\hline $\mathrm{Ni}$ & LVS EN ISO 17294-2:2005 & 4 & $28.04-24.05,04.07-30.07,05.09-01.10,07.11-30.11$ \\
\hline $\mathrm{Pb}$ & LVS EN ISO 17294-2:2005 & 3 & $28.04-24.05,04.07-30.07,05.09-01.10,07.11-30.11$ \\
\hline
\end{tabular}

\section{B. Measurement methods}

The measurement campaign for particulate matter and related substances composition was held from April 28 to December 31, 2007. The particulate matter measurements were done by the beta gauge method, SM200 equipment.

Measurement methods used for heavy metals; anions and cations concentration detection and accuracy is given in Table 1 .

The measurement campaign was organized to cover as wide spectrum of substances as possible. An illustrative measurement campaign is given in Table 1 as well.

The field campaign (measurements) and chemical analysis were performed by the Latvian Environmental, Geology and Meteorology Agency.

\section{RESULTS AND DISCUSSIONS}

Descriptive statistics for particulate matter and related substances during the sampling period is given in Table 2 .

\section{A. Variations of $P M_{2.5}$ and $P M_{10}$ concentrations}

The concentrations of $\mathrm{PM}_{2.5}$ and $\mathrm{PM}_{10}$ fractions of ambient airborne particulates were measured daily. The highest daily concentrations of $\mathrm{PM}_{2,5}$ reached $52.5 \mu \mathrm{g} / \mathrm{m}^{3}$ (detected on June 12, 2007), but the lowest $1.3 \mu \mathrm{g} / \mathrm{m}^{3}$ (detected on October 13 , 2007). The monthly concentration changes are shown in Fig. 1.

TABLE 2

DESCRIPTIVE STATISTICS FOR PARTICULATE MATTER AND RELATED SUBSTANCES DURING THE SAMPLING PERIOD

\begin{tabular}{|l|l|l|l|l|l|l|}
\hline & Maximum & Minimum & Median & Mean & $\begin{array}{l}\text { Standard } \\
\text { deviation }\end{array}$ & Sampling period \\
\hline $\mathrm{PM}_{2,5}, \mu \mathrm{g} / \mathrm{m}^{3}$ & 52.5 & 1.3 & 18.0 & 20.1 & 10.1 & April - December 2007 \\
\hline $\mathrm{PM}_{10}, \mu \mathrm{g} / \mathrm{m}^{3}$ & 83.4 & 3.5 & 24.0 & 27.5 & 15.4 & April - December 2007 \\
\hline $\mathrm{SO}_{4}, \mu \mathrm{g} / \mathrm{m}^{3}$ & 2.08 & 0.11 & 0.76 & 0.87 & 0.53 & April - December 2007 \\
\hline $\mathrm{NO}_{3}, \mu \mathrm{g} / \mathrm{m}^{3}$ & 0.95 & 0.08 & 0.17 & 0.29 & 0.28 & April - December 2007 \\
\hline $\mathrm{Cl}, \mu \mathrm{g} / \mathrm{m}^{3}$ & 0.13 & 0.05 & 0.08 & 0.09 & 0.03 & April - December 2007 \\
\hline $\mathrm{Ca}, \mu \mathrm{g} / \mathrm{m}^{3}$ & 0.22 & 0.07 & 0.15 & 0.14 & 0.06 & April - December 2007 \\
\hline $\mathrm{Mg}, \mu \mathrm{g} / \mathrm{m}^{3}$ & 0.07 & 0.02 & 0.03 & 0.04 & 0.02 & April - December 2007 \\
\hline $\mathrm{Na}, \mu \mathrm{g} / \mathrm{m}^{3}$ & 0.19 & 0.07 & 0.12 & 0.13 & 0.05 & April - December 2007 \\
\hline $\mathrm{K}, \mu \mathrm{gg} / \mathrm{m}^{3}$ & 0.38 & 0.04 & 0.12 & 0.16 & 0.11 & April - December 2007 \\
\hline $\mathrm{As}, \mathrm{ng} / \mathrm{m}^{3}$ & 2.14 & 0.13 & 0.31 & 0.44 & 0.47 & April - December 2007 \\
\hline $\mathrm{Cd}, \mathrm{ng} / \mathrm{m}^{3}$ & 4.35 & 0.03 & 0.29 & 0.64 & 1.09 & April - December 2007 \\
\hline $\mathrm{Ni}, \mathrm{ng} / \mathrm{m}^{3}$ & 4.29 & 0.24 & 2.09 & 2.10 & 1.06 & April - December 2007 \\
\hline $\mathrm{Pb}, \mathrm{ng} / \mathrm{m}^{3}$ & 25.15 & 1.14 & 13.31 & 13.33 & 7.70 & April - December 2007 \\
\hline
\end{tabular}




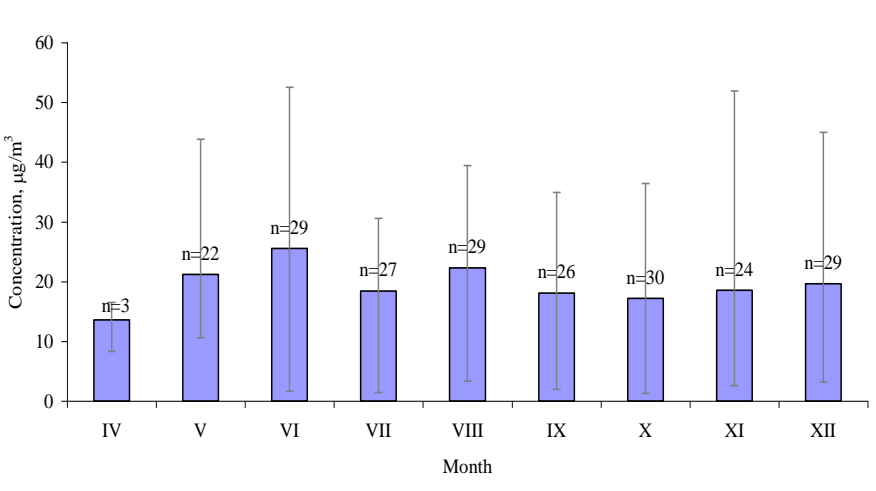

Fig. 1. Monthly variations of $\mathrm{PM}_{2.5}$ concentrations during April 28 December 31, 2007 ( $\mathrm{n}$ indicated number of observations).

The highest monthly variations of $\mathrm{PM}_{2.5}$ were detected in June and November. Unfortunately, no substantial seasonal variations have been found. For all periods of measurements, $\mathrm{PM}_{2.5}$ concentrations dominated (42\% of all cases) at a range from $11-20 \mu \mathrm{g} / \mathrm{m}^{3}$ (see Fig. 2).

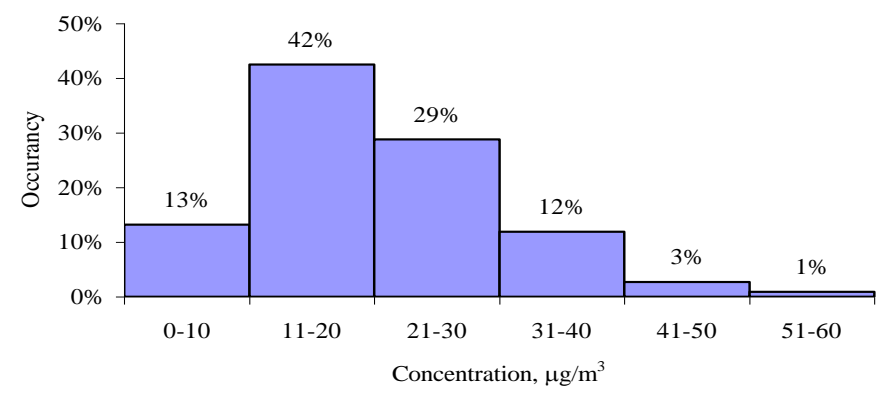

Fig. 2. Distribution of $\mathrm{PM}_{2.5}$ concentrations during April 28 - December 31, 2007.

Analysis of the $\mathrm{PM}_{2.5}$ monthly distribution shows that practically in all cases the dominating concentrations are at the range from 11-30 $\mu \mathrm{g} / \mathrm{m}^{3}$, and no seasonal differences are found.

The highest daily concentrations of $\mathrm{PM}_{10}$ reached $83.4 \mu \mathrm{g} / \mathrm{m}^{3}$ (detected on December 27, 2007), but the lowest $3.5 \mu \mathrm{g} / \mathrm{m}^{3}$ (detected on April 20, 2007). The monthly concentration changes are shown in Fig. 3.

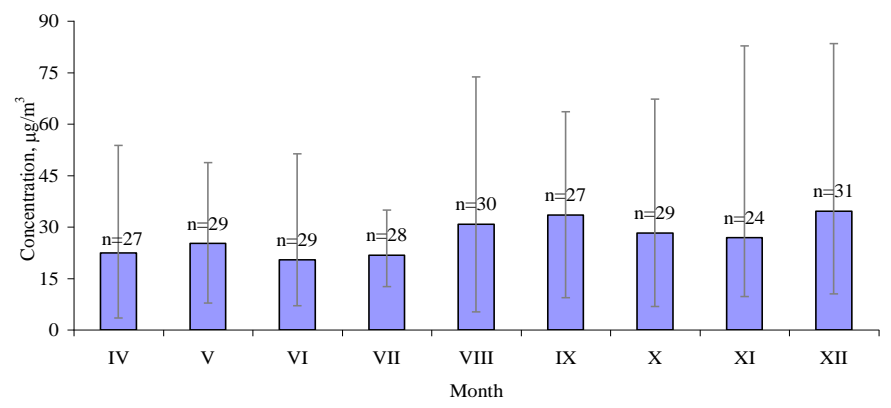

Fig. 3. Monthly variations of $\mathrm{PM}_{10}$ concentrations during April 1 - December 31, 2007 (in indicated number of observations).
The highest concentration variations are observed in the winter period, but the lowest - in the late spring - early summer period. For all period of measurements, $\mathrm{PM}_{10}$ concentrations dominated ( $58 \%$ of all cases) at a range from $11-30 \mu \mathrm{g} / \mathrm{m}^{3}$ (see Fig. 4).

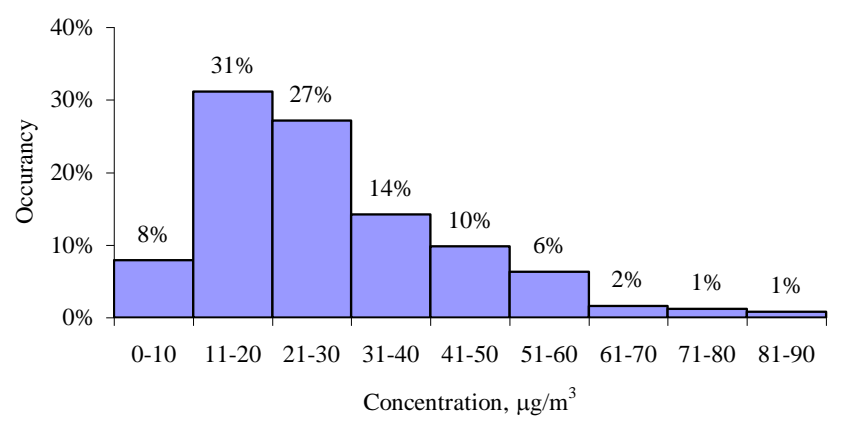

Fig. 4. Distribution of $\mathrm{PM}_{10}$ concentrations during April 1 - December 31, 2007.

According to the measurements and analysis of $\mathrm{PM}_{10}$ concentrations month by month, it has been found that during the summer time concentrations are very stable, they are changing very slowly, they do not split, which means that the influence of local sources is not so important, and the $\mathrm{PM}_{10}$ pollution level mainly originates from the long-range transboundary and background pollution.

Relationships between $\mathrm{PM}_{2.5}$ and $\mathrm{PM}_{10}$ mass concentrations were analyzed in terms of the linear regression, and the results revealed that the coefficient of determination is 0.3957 (see Fig. 5). The relatively middle coefficient shows that $\mathrm{PM}_{2.5}$ and $\mathrm{PM}_{10}$ could have both similar and different emission sources, and they could be influenced by the same local conditions. Such a relatively low coefficient of determination indicates significant contributions from primary sources, such as resuspended soil/road dust and other mechanical activities [12, $13,14]$.

Some differences were found in particulate matter concentrations during work days and weekends. In case of $\mathrm{PM}_{2.5}$ concentrations, it was determined that pollution levels are on average by $10 \mu \mathrm{g} / \mathrm{m}^{3}$ lower on weekends, in comparison with working days.

\section{B. Relationships between concentrations of particulate matter, meteorological parameters and associated components}

Some analogies found in the heavy metals analysis included: (a) concentrations $\mathrm{Ni}$ are quite variable, (b) analogies found in $\mathrm{Cd}$ and $\mathrm{As}$ concentrations variations that could be explained by origin of the same source. No relationships were found between $\mathrm{Pb}, \mathrm{Cd}$ and $\mathrm{Ni}$ variations.

Changes of $\mathrm{Ca}, \mathrm{K}$ and $\mathrm{Mg}$ had some similarities that could be explained by one group of source or, obviously, the reason of such a changes are resuspension and erosion processes (see Fig. 6, 7). 


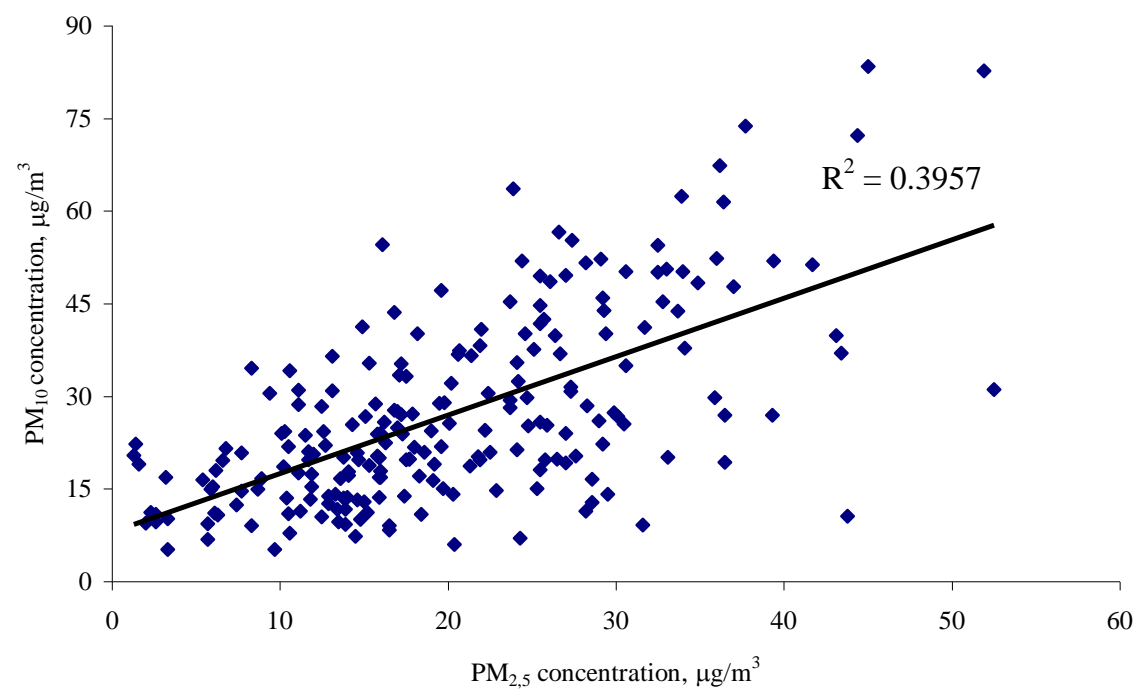

Fig. 5. $\mathrm{PM}_{2.5}$ and $\mathrm{PM}_{10}$ mass concentration ratio.

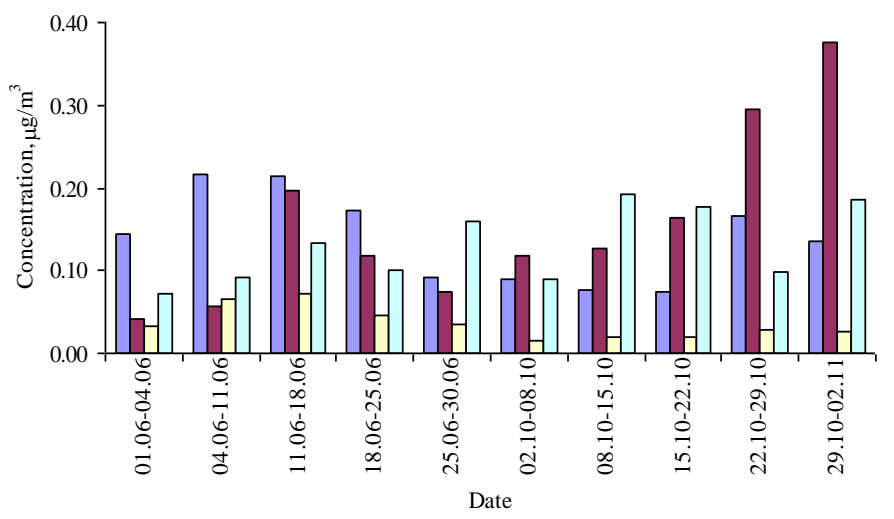

$\square \mathrm{Ca} \mu \mathrm{g} / \mathrm{m} 3 \square \mathrm{K} \mu \mathrm{g} / \mathrm{m} 3 \square \mathrm{Mg} \mu \mathrm{g} / \mathrm{m} 3 \square \mathrm{Na} \mu \mathrm{g} / \mathrm{m} 3$

Fig. 6. Concentrations of anions and cations in the $\mathrm{PM}_{2.5}$ fraction.

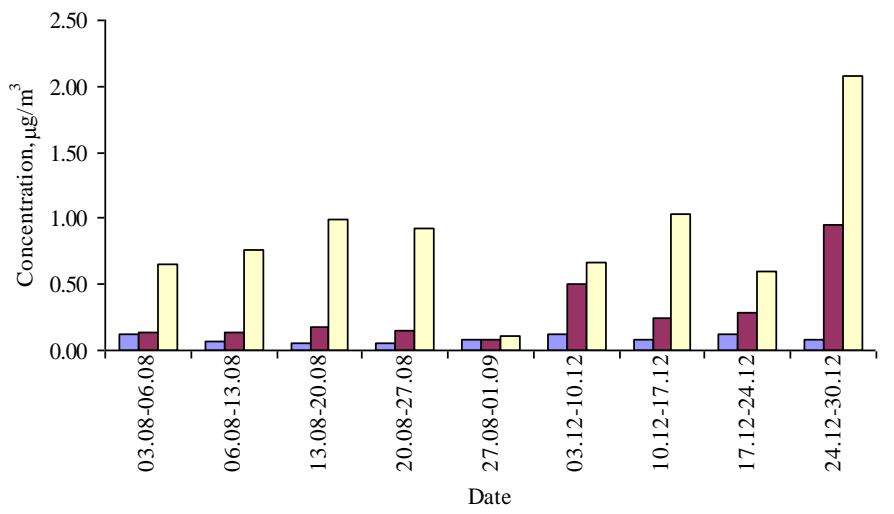

$\square \mathrm{Cl}$ mkg/m3 $\square \mathrm{NO} 3 \mathrm{mkg} / \mathrm{m} 3 \square \mathrm{SO} 4 \mathrm{mkg} / \mathrm{m} 3$
The relationships between PM, heavy metal, cations-anions concentrations and meteorological parameters (temperature, wind speed, relative humidity and precipitation) were investigated by Pearson's correlation analysis. The meteorological data, which were found to be significant in describing the variation in the 24-h averaged PM concentrations utilized in the present work, are: (1) air temperature $\left({ }^{\circ} \mathrm{C}\right)$, (2) relative humidity (\%), (3) wind speed $(\mathrm{m} / \mathrm{s})$ and $(4)$ precipitation $(\mathrm{mm})$. The correlation coefficients between the daily average $(24 \mathrm{~h})$ PM, particle-related substances and meteorological parameters are shown in Table 3 . The correlation coefficients were marked in the Table to indicate the significance levels $(P<0.01$ or $<0.05)$.

The statistically strongest correlations were detected for $\mathrm{PM}_{2.5}$-Temperature, $\mathrm{PM}_{10}$-precipitation, $\mathrm{PM}_{10}$-Ozone.

Wind speed has long been recognized as an important controlling factor on concentrations of air pollutants $[15,16$, 17, 18]. Pursuant to this study, there is no statistical relationship between wind and particulate matter pollution.

The effects of rainfall on particulate concentrations are detected. Some evidences have been found that after longer periods without rainfall particulate matter concentrations are raising, which means that PM have a tendency to accumulate in the atmosphere. Some of the above mentioned accumulation episodes have been identified, e.g. early May and July, late September, October, November and December (see Fig. 8). Moreover, precipitation is a much more effective mechanism for particulate removal from the atmosphere, in comparison with the wind speed.

Fig. 7. Concentrations of anions and cations in the $\mathrm{PM}_{2.5}$ fraction. 


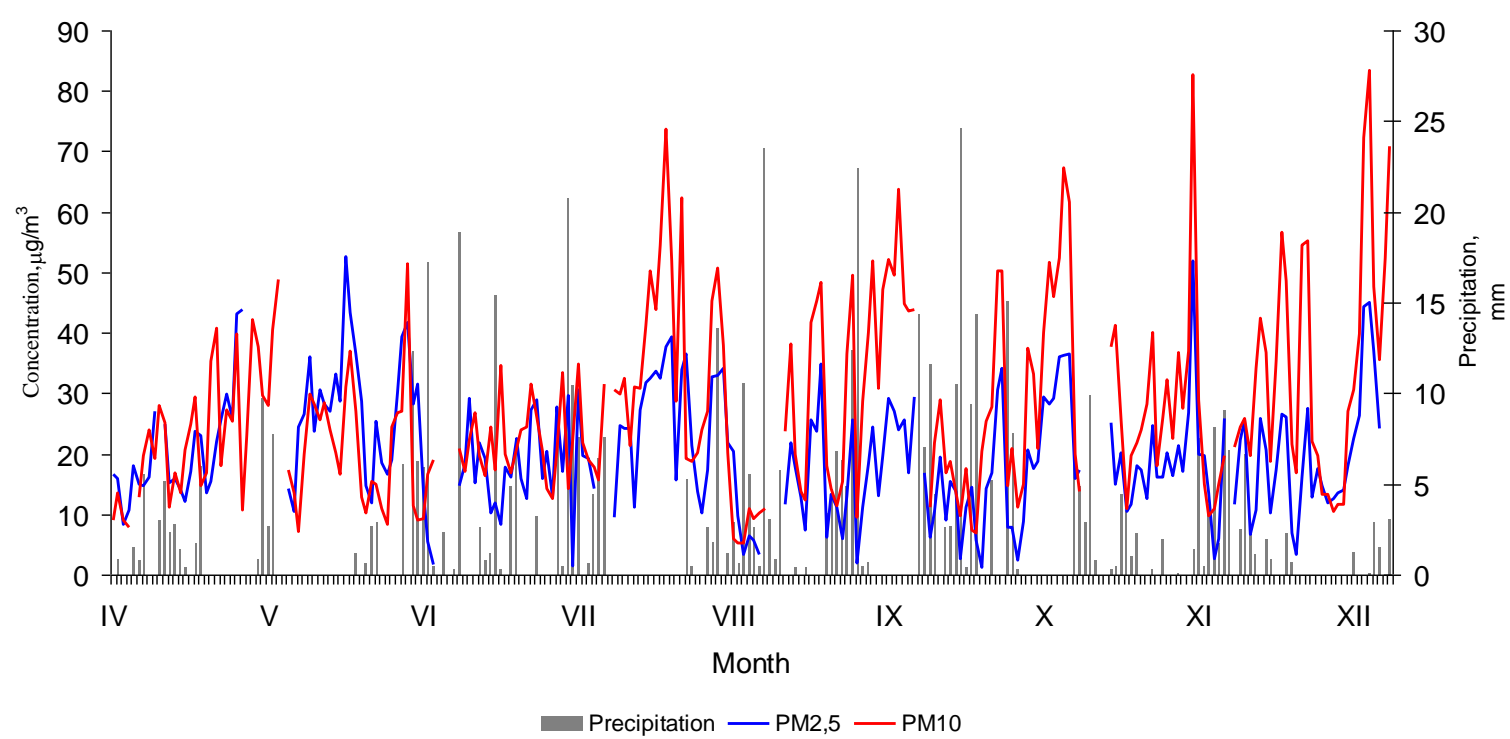

Fig. 8. Particulate matter concentration and precipitation.

TABLE 3

CORRELATION MATRIX OF PARTICULATE MATTER, PARTICLE-RELATED SUBSTANCES AND METEOROLOGICAL PARAMETERS (SIGNIFICANT CORRELATIONS AT $\mathrm{P}<0.05$ LEVEL ARE MARKED IN BOLD)

\begin{tabular}{|c|c|c|c|c|c|c|c|c|c|c|}
\hline & $\mathbf{P M}_{2.5}$ & $\mathbf{P M}_{10}$ & $\mathbf{P M}_{10} / \mathbf{P M}_{2.5}$ & $\mathbf{O}_{3}$ & $\mathrm{SO}_{2}$ & $\mathrm{NO}_{2}$ & $\begin{array}{l}\text { Precipi- } \\
\text { tation }\end{array}$ & $\begin{array}{l}\text { Tempe- } \\
\text { rature }\end{array}$ & $\begin{array}{l}\text { Wind } \\
\text { speed }\end{array}$ & $\begin{array}{l}\text { Relative } \\
\text { humidity }\end{array}$ \\
\hline $\mathrm{PM}_{2.5}$ & 1 & & & & & & & & & \\
\hline $\mathrm{PM}_{10}$ & 0.63 & 1 & & & & & & & & \\
\hline $\mathrm{PM}_{10} / \mathrm{PM}_{2.5}$ & -0.39 & 0.066 & 1 & & & & & & & \\
\hline $\mathrm{O}_{3}$ & 0.09 & -0.24 & -0.07 & 1 & & & & & & \\
\hline $\mathrm{SO}_{2}$ & 0.05 & 0.166 & -0.03 & -0.089 & 1 & & & & & \\
\hline $\mathrm{NO}_{2}$ & 0.07 & 0.065 & -0.08 & -0.344 & 0.352 & 1 & & & & \\
\hline Precipitation & -0.16 & -0.27 & 0.05 & 0.0764 & -0.082 & 0.074 & 1 & & & \\
\hline Temperature & 0.28 & 0.008 & -0.10 & 0.4902 & -0.168 & -0.251 & 0.16156 & 1 & & \\
\hline Wind speed & -0.03 & -0.07 & 0.06 & -0.141 & -0.008 & -0.162 & 0.02691 & -0.257 & 1 & \\
\hline Relative humidity & -0.13 & 0.122 & 0.04 & -0.662 & 0.175 & 0.289 & 0.22735 & -0.559 & 0.171 & 1 \\
\hline
\end{tabular}

\section{CONCLUSIONS}

Measurement of $\mathrm{PM}_{2.5}$ and $\mathrm{PM}_{10}$ fractions of ambient airborne particulates and the determination of particulate related substances have been performed in Riga (Latvia).

No seasonal variations were detected for $\mathrm{PM}_{2.5}$, but for $\mathrm{PM}_{10}$ seasonal unstable and higher concentrations were detected in the winter period.

Quite stable and inert $\mathrm{PM}_{2.5}$ pollution levels prove that no strong impact of local sources and $\mathrm{PM}_{2.5}$ pollution levels could be explained by long-range transboundary pollution and background pollution.

In case of $\mathrm{PM}_{2.5}$ concentrations, it has been determined that the pollution levels are on average lower by $10 \mu \mathrm{g} / \mathrm{m}^{3}$ on weekends, in comparison with work days.

The relatively middle coefficient shows that $\mathrm{PM}_{2.5}$ and $\mathrm{PM}_{10}$ could have both similar and different emission sources, and they could be influenced by the same local conditions. Such a relatively low coefficient of determination indicates significant contributions from primary sources, such as re-suspended soil/road dust and other mechanical activities.

Variable concentrations of $\mathrm{Ni}$ ions indicate a pollution source with the periodical operational regime, which could be liquid petroleum furnaces or suchlike.

Similar variations of $\mathrm{Cd}$ and $\mathrm{Ni}$ ions indicate a legal/nonlegal waste incinerator.

Quite high concentrations of $\mathrm{Pb}$ ions could be associated with the intensive traffic flow.

Similar variations of $\mathrm{Ca}, \mathrm{K}$ and $\mathrm{Mg}$ ions could be associated with one type of source or the reason for such high concentrations must be resuspension and/or erosion processes.

The statistically strongest correlations were detected for $\mathrm{PM}_{2.5}$-Temperature, $\mathrm{PM}_{10}$-precipitation, $\mathrm{PM}_{10}$-Ozone.

The effects of rainfall on particulate concentrations are detected. Some evidences have been found that after longer periods without rainfall particulate matter concentrations increase, which means that PM have a tendency to accumulate in the atmosphere. 


\section{REFERENCES}

1. Holland, W.W, Bennett, A.E, Cameron, I.R, et. al. Health effects of particulate pollution: reappraising the evidence. American Journal of Epidemiology, 1979, vol. 110, p. 527-659.

2. 2006 National Ambient Air Quality Standards for Particle Pollution. [Online] WHO library, 2005- [Accessed 29.12.2009.]. Available: http://www.epa.gov/ttn/ecas/regdata/RIAs/Executive\%20-Summary.pdf.

3. Wilson, A.M., Salloway, J.C., Wake, C.P., et. al. Air pollution and the demand for hospital services: a review. Environment International, 2004, vol. 30, p. 1109-1118.

4. Chakra, O.R.A., Joyeux, M., Nerriere, E., et. al. Genotoxicity of organic extracts of urban airborne particulate matter: an assessment within a personal exposure study. Chemosphere, 2007, vol. 66, p. 1375-1381.

5. Hu, M., Ling, Y.H., Zhang, Y.H., et. al. Seasonal variation of ionic species in fine particles at Qingdao, China. Atmospheric Environment, 2002, vol. 36, p. 5853-5859.

6. Wang, G.H., Huang, L.M., Gao, S.X., et. al. Characterization of watersoluble species of PM10 and PM2.5 aerosols in urban area in Nanjing, China. Atmospheric Environment, 2002, vol. 36, N 8, p. 1299-1307.

7. Wang, Y., Zhuang, G.S., Sun, Y.L., et. al. The variation of characteristics and formation mechanisms of aerosols in dust, haze, and clear days in Beijing. Atmospheric Environment, 2006, vol. 40, p. 6579-6591.

8. Tang, I.N., Fung, K.H., Imre, D.G., et. al. Phase transformation and metastability of hygroscopic microparticles aerosol. Aerosol Science and Technology, 1995, vol. 23, p. 443-453.

9. Dougle, P.G., Vlasenko, A.L., Veefkind, J.P., et. al. Humidity dependence of the light scattering by mixtures of ammonium nitrate, ammonium sulfate and soot. Journal of Aerosol Science, 1996, vol. 27, p. S513-S514.

10. Lee, C.G., Yuan, C.S., Chang, J.C., et. al. Effects of aerosol species on atmospheric visibility in Kaohsiung city, Taiwan. Journal of the Air \& Waste Management Association, 2005, vol. 55, p. 1031-1041.

11. Yuan, C.S., Lee, C.G., Liu, S.H., et. al. Correlation of atmospheric visibility with chemical composition of Kaohsiung aerosols. Atmospheric Research, 2006, vol. 82, p. 663-679.

12. Perez, N., Pey, J., Querol, X., et. al. Partitioning of major and trace components in $\mathrm{PM}_{10}, \mathrm{PM}_{2.5}, \mathrm{PM}_{1}$ at an urban site in Southern Europe. Atmospheric Environment, 2008, vol. 42, p. 1677-1691.

13. Querol, X., Alastueya, A., Ruiz, C.R., et. al. Speciation and origin of $\mathrm{PM}_{10}$ and $\mathrm{PM}_{2.5}$ in selected European cities. Atmospheric Environment, 2004, vol. 38 , p. 6547-6555.

14. Chan, C.K., Yao, X. Air pollution in mega cities in China. Atmospheric Environment, 2008, vol. 42, p. 1-42.
15. Harrison, R.M., Yin, J., Mark, D., et. al. Studies of the coarse particle (2.5 10 microns) component in UK urban atmospheres. Atmospheric Environment, 2001, vol. 35, p. 3667-3679.

16. Turalı, F.S., Nuho, A., Bayraktar, H. Impacts of some meteorological parameters on SO2 and TSP concentrations in Erzurum, Turkey. Chemosphere, 2005, vol. 59, p. 1633-1642.

17. Chaloulakou, A., Kassomenos, P., Spyrellis, N., et. al. Measurements of $\mathrm{PM}_{10}$ and $\mathrm{PM}_{2.5}$ particle concentrations in Athens, Greece. Atmospheric Environment, 2003, vol.37, p. 649-660.

18. Motelay-Massei, A., Ollivon, D., Garban, B., et. al. M. Polycyclic aromatic hydrocarbons in bulk deposition at a suburban site: assessment by principal component analysis of the influence of meteorological parameters. Atmospheric Environment, 2003, vol. 37, p. 3135-3146.

19. Report for the Stage $\mathbf{3}$ in-depth review of emission inbentories submitted under the UNECE LRTAP Convention and EU National Emissions Ceilings Directive for Latvia. United Nations. Economic and Social Council, 2009. [Accessed 25.04.2011.] Available: http://ceip.at/fileadmin/inhalte/emep/pdf/2009/LV_Stage3_Review_Report_ 2009.pdf

20. EMEP Source-Receptor Relationships. Yearly SR tables country-to$\begin{array}{llll}\text { country. } & \text { [Accessed } & \text { 14.02.2011.] Available: }\end{array}$ http://www.emep.int/SR_data/index_sr.html.

21. Central Stattistical Bureau of Latvia. [Accessed 12.09.2011. Available: http://www.csb.gov.lv.

22. Rīgas Brīvostas pārvalde. Fakti un skaiții, 2010. [Accessed 15.06.2011.] Available: http://www.rop.lv/lv/par-ostu/fakti-un-skaitli.html.

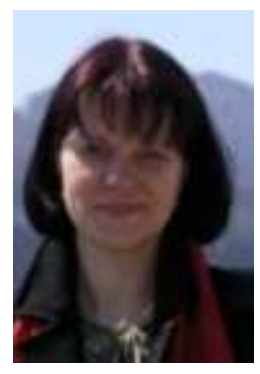

Iveta Šteinberga, Dr. Geogr., Assistant Professor, University of Latvia, Faculty of Geography and Earth Sciences. Assistant Professor Iveta Šteinberga has been part of academic staff of Faculty since 2005 and Head of Modelling laboratory of Environmental processes. The main research areas are modelling of environmental pollution (ordinary pollutants, noise) processes in atmosphere and ecosystems, assessment of particulate matter pollution. She has Chemical Engeneer Diploma (1999) and Doctoral degree diploma in Environmental Science (2007). PhD thesis "Modelling of quasistatical air pollution levels" was defended in University of Latvia in Faculty of Geography and Earth Sciences. Address: Alberta street 10, LV1010, Riga, Latvia

Phone: +37126467809

E-mail: iveta.steinberga@lu.lv

Iveta Šteinberga. Cieto daḷinuu un to sastāva izmaiṇu variāciju novērtējums

Cieto dạinun $\left(\mathrm{PM}_{2.5}\right.$ un $\left.\mathrm{PM}_{10}\right)$ piesārṇojuma līmeṇa un to sastāva mērijumi veikti Rīgā laika posmā no 2007. gada aprị̣a līez decembrim. Piesārnojošo vielu koncentrācijas gaisā galvenokārt ir atkarīgas no to apjoma un meteorologiskajiem apstākḷiem. Īpaši dažādu meteorolog̣isko faktoru loma ir noz̄imīga sekundāro cieto dalinnu rašanās procesā.

Cieto dalinu koncentrāciju mērījumi veikti izmantojot Beta-radiācijas metodi (iekārta SM200), anjonu koncentrācijas noteiktas atbilstoši LVS EN ISO10304-2004 standartam, katjonu un smago metālu - LVS EN ISO 17294-2-2005 standartam. Mērijumi veikti Latvijas Vides, Geologijas un Meteorologijas centrā.

Galvenie secinājumi: (1) novērtējot $\mathrm{PM}_{2,5}$ koncentrācijas, sezonālas variācijas netika konstatētas, augstākās $\mathrm{PM}_{10}$ koncetrācijas konstatētas ziemas periodā, bez tam, tām novērota augsta mainība (nestabilitāate); (2) salīdzinoši inertās un stabilās $\mathrm{PM}_{25}$ koncentrācijas nav saistāmas ar lokālu piesārnojuma avotu ietekmi, bet gan ar pārrobežu un fona piesārņojumu; (3) novērtējot $\mathrm{PM}_{2.5}$ koncentrācijas konstēts, ka brīvdienās to piesārņojuma līmenis ir vidēji par $10 \mu \mathrm{g} / \mathrm{m}^{3}$ zemāks nekā darba dienās; (4) līez̄gā $\mathrm{PM}_{2.5}$ un $\mathrm{PM}_{10}$ mainība norāda uz kopēja piesārnojuma avota eksistenci, kā arī līdz̄ịu meteoroloǵisko faktoru ietekmi sekundārā PM rašanās mehānismā; (5) lielā nikẹla jonu koncentrācija norāda uz lokālu piesārṇojuma avotu, piemēram, šsidrā kurināmā sadedzināšanas iekārtu, (6) niķ̣eḷa un kadmija jonu izmaiņu līdz̄̄ba norāda uz tuvumā esošu legālu/nelegālu atkritumu sadedzināšanas iekārtu, (7) līdzị̄ās kalcija, kālija un magnija jonu koncentrāciju izmaiņas norāda uz kopēju piesārņojuma avotu, visticamāk resuspensijas vai erozijas procesiem; (8) statistiski būtiskākās koкelācijas konstatētas starp $\mathrm{PM}_{25}$-gaisa temperatūra, $\mathrm{PM}_{10}$-nokrišṇi, $\mathrm{PM}_{10}$-ozons.

\section{Ивета Штейнберга. Оценка изменений вариации аэрозолей и их состава}

Измерения уровней загрязнения аэрозолей $\left(\mathrm{PM}_{2,5}\right.$ и $\left.\mathrm{PM}_{10}\right)$ и их состава проводились с апреля по декабрь 2007 года в Риге. Концентрации загрязняющих веществ в воздухе в основном зависит от их объъема и метеорологических условий. Разные метеорологические факторы особенно важны в жизненном цикле аэрозолей. Измерения концентрации аэрозолей проводились с использованием метода бета-радиации (прибор SM200), концентрации анионов определились соответственно стандарту LVS EN ISO 10304-2004, катионов и тяжёлых металлов - стандарту LVS EN ISO 17294-2-2005. Измерения проводились в Центре окружающей среды, Геологии и иетеорологии Латвии.

Главные выводы: (1) оценивая концентрации $\mathrm{PM}_{25}$, сезональные вариации не констатированы, самие высокие концентрации $\mathrm{PM}_{10}$ констатированы в зимний период, кроме того наблюдалась высокая их изменчивость (нестабильность); (2) относительно инертные и стабильные РМ $_{25}$ концентрации связанны не с локальными источниками загрязнения, а с трансграничным и фоновым загрязнением; (3) оценивая концентрации $\mathrm{PM}_{2.5}$ констатированно, что в выходные дни уровень их загрязнения в среднем на $10 \mu \Gamma / \mathrm{M}_{3}$ ниже, чем в рабочие дни; (4) похожая изменчивость $\mathrm{PM}_{2.5}$ и $\mathrm{PM}_{10}$ указывает на общий источник загрязнения, а также на влияние похожих метеорологических факторов в механизме появления РМ; (5) большая концентрация никелевых ионов указывает на локальный источник загрязнения, например, устройство сжигания жидкого топлива; (6) сходство изменении никелевых и кадмиевых ионов указывает на находящейся по близости легального/нелегального устройства сжигания отходов; (7) сходство изменении концентрации ионов кальция, калия и магния указывает на общий источник загрязнения, скорее всего на процессах ресуспенсии или эрозии; (8) статитически существенные кореляции обнаружены между $\mathrm{PM}_{25}$-температура воздуха, $\mathrm{PM}_{10}$ -

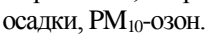

